\title{
Change of Scale: Home Movies as Microhistory in Documentary Films
}

Efrén Cuevas

Reference: Cuevas, Efrén, "Change of Scale: Home Movies as Microhistory in Documentary Films", in Laura Rascaroli, Gwenda Young and Barry Monahan (eds.), Amateur Filmmaking: the Home Movie, the Archive, the Web, Bloomsbury, New York and London, 2014, pp. 139-151

http://www.bloomsbury.com/us/amateur-filmmaking-9781441191496/

In the last two decades, a significant number of documentary filmmakers have used home movies to create films that can be termed "historical," insofar as they use domestic footage to provide portrayals of past times and societies. These documentaries are not built around grand historical events, but around the quotidian episodes of the different families portrayed, and thus suggest a way of looking at the social fabric that is close to the sociological studies of everyday life and analogous to the historiographical approaches of studying "history from below," used by the Italian microstoria or the German Alltagsgeschichte. In this chapter, I intend to analyze those links, first by examining why home movies are a valuable source for a sociological study of everyday life and/or a history from below. Then, I will focus on how documentaries made out of home movies enter into dialogue with those approaches, and examine to what extent they can be understood as the filmic equivalent of the microhistorical studies written by professional historians. In order to achieve this, I will analyze the two basic types of structures of these films: the collective chronicles composed from a wide collection of domestic footage; and the films that focus on a single family, whether autobiographical or not.

\section{Home Movies as Documents for a History of Everyday Life}

The growing interest in home movies within academia has not yet brought to the forefront the connection with related fields such as everyday life studies or microhistory. Scholars from these fields rarely focus on home movies as sources of their analysis, and while film scholars have paid some attention to them, there is still much ground to cover. ${ }^{1}$ The essays included in Mining the Home Movie (Ishizuka and Zimmermann 2011) probably constitute the main effort in this direction, although they are rather more focused on archival issues and standard historical approaches. Patricia Zimmermann (2011), in her introductory chapter to that collection, addresses these questions more clearly. When considering the role of home movies in history, she stresses how recent research examines their hermeneutic possibilities, looking at how 
they "can function as a recorder, an interrogator, a deferral, a condensation, and a mediator of historical traumas that extend beyond the self, such as labor, war, race, gender, religion, illness, diaspora, and displacement" (5). She also suggests that when this domestic footage is used in contemporary media productions, it is conceptualized "as microgeographies and microhistories of minoritized and often invisible cultures that are social and highly political” (18).

Home movies therefore need to be conceptualized as more than just an interesting visual archive for standard historical accounts, which complements other traditional sources. It is also necessary that they be understood as the most suitable filmic document to study "history from below" as proposed by microhistorical approaches. With important scholars in the Mediterranean area-such as the Italians Carlo Ginzburg and Giovanni Levi and the French Jacques Revel-microhistory takes a change of the scale of observation as its main premise. Historians employing this approach posit that the grand narratives of traditional history do not capture the real significance of the times and the people. Instead, microhistorical approaches ask for a new scale, which will produce a new type of historical knowledge because, as Revel (1996) states, "varying the focal length of the lens is not simply about enlarging (or shrinking) the size of the object caught in the viewfinder: it's about altering its shape and framing... it's actually changing the very content of what is being represented (in other words, the decision about what is actually representable)" (19; translation by Barry Monahan). Such an approach also reacts against the more deterministic or functionalist historiography, prevalent until the 1970s (the French Annales, the North American cliometrics, the Marxist approaches); and against the longue durée structures linked to these trends. Instead, microhistorians "affirm the human agency of past men and women at every level of society, but always within a specific, concrete network of social relationships" (Gregory 1999, 103). The microhistorical framework fits quite appropriately with the approach found in home moviemaking, always centering on individuals and families, with a continuous focus on the small scale of their environments.

The very nature of home movies also concords with the concept of the miniature, outlined by Alf Ludtke (1995) in his explanation of the basics of a history of everyday life (Alltagsgeschichte), to stress again the small scale, where "the 'density' of life situations and contexts of action can be made vivid and palpable" (21). ${ }^{2}$ Ludtke proposes creating a collage or mosaic with those miniatures to form societal "patchwork" structures, linking them together in a network of interrelations. In doing so, he addresses one of the main problems of these approaches: how to apply the knowledge acquired with the micro scale to the larger historical frameworks (14). This is what Francesca Trivellato (2011) also addresses in her study of the links between micro-, macro-, and global histories. She finds these scales relate to each other best 
within the narrative framework proposed by microhistorians, with an emphasis on biographical studies, since the study of individuals with global microhistories may bridge the gap between the different scales. Home movies do not fit into this pattern directly, since they lack a narrative framework and are rather undecipherable for anyone outside of the circle of family members. Providing a narrative structure for the general public will be the task of contemporary filmmakers when recycling domestic footage in order to compose filmic microhistorical canvases, as we will study in the following sections.

\section{Collective Portraits}

To begin with, we will focus on the case of filmmakers using home movies to build collective portraits of a generation or a minority. Some of these films can qualify as compilation films, usually made for television and sometimes mixing professional, amateur and home movies. Here we will examine three cases that go beyond the standard compilation documentary and that show distinctive ways of recycling home movies: Private Chronicles. Monologue (Liner Nahimov, Russia, 1999); Memory of Overseas Territories (Mémoire d'outremer, France, 1997); and Something Strong Within (U.S.A., 1994). ${ }^{3}$

Private Chronicles. Monologue offers a portrait of Russian society from the 1960 s to the 1980s, exclusively using home movies from that period. Arranging them by years (from 1961-1986), filmmaker Vitaly Manskij selects from a vast collection and applies a fictional framework: the pretend autobiography of a Russian - speaking in voiceover-born in 1961. Manskij stresses the hybrid nature of the film by placing his fictional protagonist within a solid historical frame. This is achieved by beginning and ending each chapter with a caption specifying the year, accompanied by a photograph, frequently of protagonists of the public history of that period. The overall result is not completely satisfying because Manskij often seems to look for an all-too-perfect match between image and voiceover, dismantling the naïve truth-value character of the home movies, and foregrounding the ready-made dimension of the format. Despite this weakness, the image track offers a rather surprising portrait of the Russian society of that time, far different from the stereotypes of the Soviet Regime that western spectators most likely had: celebrations, dinners, dancing, vacations in seaside resorts, and so on, all shot by domestic filmmakers using small-gauge cameras, a commodity typically associated with capitalist societies. Nonetheless, these "private moments" are still intermingled with the filming of events usually associated with the official public image of the regime, such as the typical Soviet military parades.

This film therefore represents an interesting example of how the change of scale provides new insights in the portrayal of a generation, one that leaves aside the 
stereotypes of the mainstream media. Likewise, it shows how home movies reflect the understanding of everyday life suggested by Michel de Certeau (1984): as a site of resistance against the standardization promoted by the institutional powers. This resistance - a mixture of given inertias and inventive deviations - is to be found, according to de Certeau, in how 'popular procedures (also 'miniscule' and quotidian) manipulate the mechanisms of discipline and conform to them only in order to evade them" (xiv). In this context, home movies can clearly qualify as one of the "the innumerable practices by means of which users reappropriate the space organized by techniques of sociocultural production," therefore bringing to light "the clandestine forms taken by the dispersed, tactical, and makeshift creativity of groups or individuals already caught in the nets of "discipline"” (xiv-xv). In Private Chronicles. Monologue, the scenes of everyday life show little of the orthodoxy appropriate to an official Marxist state. Instead, they resemble scenes familiar from westernized societies, with their citizens' attachment to habits of leisure and consumerism. They also show a certain clash between private and public spaces, linking the celebration of parties and dancing to private homes, in contrast to the official celebrations (with military parades as their prototype) that occupy the public sphere.

The storyline provided by the fictional protagonist does not hinder the film from offering a rather sketchy representation of the Russian society of that time. The very nature of home movies, with filming open to random situations and with no professional planning, nurtures this image; their gathering in a single film fostering the collage effect. This outcome in fact reinforces the representation of "everydayness," which comes to life in its fullest, according to Ben Highmore (2002), when it is characterized by an improvised quality (24-6). Highmore proposes Impressionist painting as exemplary of this approach, but the same argument can be applied to home movies, because they also combine subject matter and form to capture that unscripted and sketchy condition of the everyday. Home movies do not intend, obviously, to offer a systematic study of everyday life, because they usually avoid the grim aspects of family life. Yet despite their partiality, they truly succeed in showing the everyday life in a way no other visual format, either fiction or documentary, has managed.

These issues are also visible in the French film Memory of Overseas Territories, which deals with the life of French colonizers from the 1920s to the 1960s. Filmmaker Claude Bossion makes his film using home movies shot by people living in the colonies, mixing scenes from different countries and appearing to keep a chronological order (although many of them are not explicitly dated). The soundtrack, nevertheless, reinforces the collage effect of the overall film since it employs very different verbal sources (often unrelated to the images): official reports, encyclopedia entries, personal and official letters, interviews to some of the actual home moviemakers or to the people filmed, etc. The combination of visual and verbal sources from different times and 
places creates a polyphonic text that looks for resonance beyond the standard watching of home movies, foregrounding that sketchy and unscripted condition mentioned by Highmore as a key feature in the representation of everydayness.

This portrait of the colonizers intends to offer new insights into the history of colonization, not so much related through the macrohistorial framework (although some of the verbal sources give context or commentary in this sense), but rather through the history of their everyday life, thus coming closer to the approach of Alf Ludtke and other microhistorians. With this approach in mind, it seems inevitable that a nostalgic mood for a bygone way of life becomes a part of the fabric of the film. However, this nostalgic component does not imply a justification of the problems linked to colonization, as Rachael Langford (2005) seems to argue, since the film does not intend to offer a standard macrohistorical explanation or to examine its well-known sociopolitical conflicts. Langford laments the absence of "images of political meetings, demonstrations, bombings, or police actions," which, according to her, makes the film present colonialism not "as a struggle, but as a consensual project" (107), and as "a private affair" (108). Her interpretation, however, seems to forget the nature of the visual material used in the film, a misunderstanding that can be seen also in her classification of the images as "amateur films" and never as home movies. While some scholars consider home movies as a type of amateur filmmaking, there are important differences between them (taking both modes in a strict sense). These discrepancies are relevant to this context: amateur filmmakers aim to make films-fiction or documentary - that are to be shown in public and thus emulate professional standards (including the editing); on the other hand, home moviemakers mainly shoot their daily activities or events happening in their surroundings, to be shown just in family gatherings. ${ }^{4}$ Therefore, when Claude Bossion decides to make a film out of home movies, the material itself determines the nature of his film, which will look at colonization from a microhistorical approach. Its portrait of everyday life cannot be considered false or fictional, as Langford describes it (108), because it speaks about the colonization from a different perspective, through the ordinary situations shown by the home movies. It is through this domestic footage that the spectator learns about the social and working differences between the French colonizers and the African people, thus revealing the quotidian consequences of colonization.

Something Strong Within also deals with historical contrasts in its representation of the everyday life of the Japanese American community incarcerated in camps in the U.S.A. during the Second World War. The events have been depicted in fiction and documentary films in the last decades, with Something Strong Within standing out as one of the most poignant portraits. Filmmakers Robert Nakamura and Karen Ishizuka used footage shot by people imprisoned in the camps, and added music composed by Dan Kuramoto, an introductory text, and several quotations throughout the film, as well 
as the photographs and names of the home moviemakers. The collective portrait provided by this film becomes a very interesting example of the potential of home movies as historical documents, since it focuses on a well-known historical event, now seen through a microhistorical lens. It clearly becomes an alternative narrative of those events, in contrast to the official newsreels that attempted to offer a rationale of the forced internment, reflecting, as Ishizuka (2010) states, "the dialectics of a community reinventing itself within a uniquely colonized socio-political environment of containment" (216). ${ }^{5}$ The home movies depict many of the usual routines of family life, but here with the ominous background of tar-paper barracks and guard towers. They also incorporate other scenes not so typical of home moviemaking, such as views of the empty landscapes around the camps, or communal activities (meals, games, etc.). The capturing of such images shows a level of self awareness on the part of the home moviemakers; a recognition of the historical importance of keeping some visual trace of these events. This example of "history from below" also depicts the everyday life of the community as a clear act of resistance, this time in the face of enduring circumstances, as Robert Rosen (2008) explains: "They resisted the inclination to lose hope in the face of daunting challenges ... to deny a cultural identity and community solidarity that had singled them out for persecution in the first place, and, most surprising of all, to abandon their commitment to a nation that had abandoned them" (120). This last paradox is explicitly visualized in the film in one of the most surprising scenes: the visit of a sergeant, who was fighting in the 442nd Infantry Regiment, which was composed entirely of Japanese-American volunteers. The genuine celebration of his visit-and very existence of his regiment-conveys the puzzled multicultural identity of this community: proud to be American and eager to show it at a time when the system was openly challenging their Americanness. It is this that is so central to Something Strong Within, a film that encapsulates so effectively the efforts of Nakamura and Ishizuka to bring back to public attention the history of this community and its struggles in the face of such a historical hardship. ${ }^{6}$

\section{Microhistorical Family Narratives}

Besides these collective portraits, we can find a significant number of films that use home movies to compose personal and family portraits deeply embedded in their historical contexts. These films offer a closer proximity to the best-known examples of Italian microstoria, since these historians usually propose an in-depth study of an individual or a family as the route through which a historical period can be understood.. As Edward Muir (1991) explains, "to the microhistorians the makers of history are seldom 'great men' but rather the little peoples lost to European history" (x). They trace the lives of individuals, resulting in "a prosopography from below in which the relationships, decisions, restraints, and freedoms faced by real people in actual 
situations would emerge" (ix-x). They also employ a narrative approach in their research because it can better show, as Giovanni Levi (2001) suggests, "the true functioning of certain aspects of society which could be distorted by generalization and quantitative formalization" (105-6). This approach clearly resonates in the films of Péter Forgács, but also in other less-known films such as $Y$ in Vyvorg (Finland, 2005), For My Children (Israel, 2002) or I for India (UK, 2005). ${ }^{7}$

Both $Y$ in Vyvorg and many of Forgács's films cover events from the 1930s and 1940s, and are concerned with the war conflicts of those times. Y in Vyvorg focuses on the Ypyä family from 1939 to 1949. Residents of Vyvorg, the wife and the children had to leave the city when the Soviet Union tried to invade the country. Remarkably, both husband and wife kept making home movies during those years of separation. Filmmaker Pia Andell reconstructs this period using their home movies and letters, moving away from a standard historical documentary and instead offering an account of the war through the experiences of this family. Her film shows the contrasts during these years: the times of peace and the times of war; life in the home front and life in Vyvorg. She adds a new dimension by using the family letters, which openly narrate the hardships of war and separation, adding new overtones to the domestic images of happy children or daily routines. A basic historical framework is provided through a voiceover fictionally assigned to two of the daughters. Yet the strength of $Y$ in Vyvorg does not rely on its historical data, but on its microhistorical portrayal of the war, as lived by the Ypyä family. This approach clearly echoes the goal pointed out by Giovanni Levi (2001) for microhistorians: "their work has always centred on the search for a more realistic description of human behavior, employing an action and conflict model of man's behavior in the world which recognizes his - relative-freedom beyond, though not outside, the constraints of prescriptive and oppressive normative systems" (94). It is difficult to imagine a more oppressive setting than a war period, and the film succeeds precisely in portraying the struggles of the Ypyä family within this setting, using for its purpose domestic footage, a fitting visual source for the small-scale research intended by Pia Andell.

Péter Forgács applies a similar approach in all his films, often focused on the history of a single family: Dusi and Jenő in the film of the same title (1989); György Petö and Eva in Free Fall (1996); the Peerebooms in The Maelstrom (1997); Joan Salvans and Ernesto Díaz Noriega in The Black Dog (El perro negro, 2004); and Lisl Goldarbeiter and her cousin Marci in Miss Universe 1929 (2006). ${ }^{8}$ Forgács thus maintains the microhistorical perspective as a distinctive feature of his work, looking at complex historical periods of the last century through the lens of individual lives. Nevertheless, he does not try to approach his films as a professional historian, but as a filmmaker. His thorough documentation and detailed editing of the footage is complemented with other expressive techniques, such as tinting and toning, freeze 
framing, slow motion and the distinctive music of Tibor Szmezö; all of them amplifying the meaning of the images, striving for a balance between a historical account and an emotional portrait of the period.

Among Forgács's work, probably one of the most discussed films is The Maelstrom. ${ }^{9}$ Here he approaches the Holocaust from the perspective of a Jewish Dutch family, the Peeremboom, using their home movies as the main visual source. Forgács shows a strong historical consciousness in his approach, skillfully connecting the small scale with the general historical framework. To achieve this, he complements the domestic footage of the Peeremboom with titles that supply factual information about the legal persecution of the Jewish people in Holland, and sound recordings of public speeches of that time. Achieving a neat balance between the macro and the micro, he reinforces the historical dimension by the inclusion of the home movies of SeyssInquart (the Reich Commissioner for the Netherlands) and his family. The interplay between the two domestic sources creates a powerful and poignant contrast and complicates viewers' responses. The home-movie style calls for a sympathetic answer from the public, but our historical knowledge keeps us from a benevolent reception of the Seyss-Inquart family footage, and thus provokes an ambivalent reaction in us. On the other hand, the stylistic and subject matter similarities between the two domestic sources reinforce the latent tragedy of the Jewish family. Watching their ordinary routines, the spectator develops a strong sense of anxiety, since the protagonists show such a tragic ignorance of the real threads of their time, as we can see particularly in the images of their naïve preparations to travel to Auschwitz. The Maelstrom presents itself as a masterful piece of microhistorical research into a historical period well known to the spectator, one that succeeds in creating a deeper understanding of the historical era.

Many filmmakers have used home movies of their own families to create family portraits with strong historical echoes, adding an autobiographical perspective to the recycling of the domestic footage. In some cases, these films present a structure similar to the compilation film, and their tone comes closer to a visual study of the everyday life of a particular society, such as The Paternal Line (La línea paterna, México, 1994) or The Artificial Horizon (El horizonte artificial, Spain, 2007). In other cases, the home movies give way to films more embedded in historical contexts, such as I for India or For My Children. Both films employ diverse visual sources, with home movies standing out among them.-In Michal Aviad's For My Children the home movies are used sparingly, but they are blended with Aviad's specific filming of her family for this project. Nevertheless, the goal of the film goes beyond the limits of her family, delving into the history of Israel to understand what its future will be and thus producing a remarkable work about the intermingling of micro- and macrohistories. Paraphrasing the microhistorical theses of Giovanni Levi (2001), Aviad gains access to a knowledge of the past with an approach that "takes the particular as its starting point ... and 
proceeds to identify its meaning in the light of its own specific context" (106). This approach is not seen as a coherent system: instead, it makes its contradictions visible, "the fragmentation ... and plurality of viewpoints which make all systems fluid and open" (107). For My Children offers a version of the history of Israel that includes the contradictions of the system, expressed by the members of the family.

The film also provides a good example of how the study of an individual case can be the best way to understand the general framework, as Levi (2001) says, "since minimal facts and individual cases can serve to reveal more general phenomena" (109). Aviad stresses the connection between her autobiographical account and the macrohistorical context by employing different strategies: the typical use of public archival footage; the inclusion of present public events as seen in the television news; and, most importantly, the testimonies of her family (grandparents, husband, brother-inlaw) as the guides to remember and reevaluate the history of Israel. Her film therefore offers a rich dialogue between family history and public history, becoming a powerful case of a chronicle of everyday life embedded in public events.

In I for India filmmaker Sandhya Suri employs the correspondence composed of home movies and audiotapes sent between her father and her relatives in India, beginning in 1965 when he immigrated to England with his wife and children to work as a doctor. In the first part of the film, Suri recycles all of this material, mixing home footage and audio recordings that were originally recorded separately. The happy nature of the domestic images takes on a new meaning once it is complemented by the audio recordings, creating a bittersweet effect in which the sadness of separation predominates. ${ }^{10}$ The second part of the film shows the return of Suri's family to India in 1982, a stay that was unsuccessful and caused them to come back to England again. Interestingly, during their years in India her father hardly shot any home movies, as if they only made sense as a way of keeping the family together when they were far away. This is a revealing sign of the role domestic communication technologies-films, videos and ultimately the Internet - play in this film, as a crucial way of maintaining the communal identity of the diasporic family. It demonstrates the primary role of home movies - as Odin (1995) points out - in strengthening the family group, providing a mythical anchor that protects it from the contingencies of time and the tests to which it is subjected by the world (32-3). This function is even more present in transnational families like Sandhya Suri's, since the home movies work here as an umbilical cord that keeps the family bonds alive despite the distance that separates them. Moreover, the home movies of Suri's father also provide what Lebow (2012) calls "reverse ethnography" (225), a look at the British society from the vantage point of an Indian "ethnographer," expanding their meaning beyond the family circle to become a valuable social record of this period in England. 
As a whole, I for India becomes a powerful film about the processes of immigration, seen again through the microhistorical lens of a particular group. It becomes the point of access to the contemporary problems of transnational families, those "families that live some or most of the time separated from each other, yet hold together and create something that can be seen as a feeling of collective welfare and unity, namely 'familyhood', even across national borders" (Bryceson and Vuorela 2002, 3 ). Besides the small scale of observation, the film's chronological structure-which gives it a loose narrative cadence-also places it close to the methods of microhistorians, and away from macro approaches and their inability to show the inconsistencies of the system and the tensions experienced by individuals. I for India succeeds in portraying these tensions that come from the physical separation and cultural contrasts. Nevertheless, the film also manages to place these struggles in broader frameworks, through different strategies such as the contrast between the domestic footage and the public archives (as in a scene showing an excerpt from the BBC about Indian immigration in the 1960s), addressing the determination of microhistory to make the small scale meaningful for the understanding of the macrohistorical contexts.

Home movies stand out, therefore, as a valuable source for the generation of a filmic version of the "history from below" that has been cultivated in the historiography of the last decades. When recycled in contemporary documentaries, they provide a clear change of scale, offering new perspectives that enlighten well-known periods like the Second World War, or bring to the fore minorities and events marginalized by the public history or the mainstream media. Filmmakers recycle this domestic footage to make collective portraits of a generation or a minority, or to analyze historical periods through the perspective of a single family or individual, in tune with the concerns of microhistory. In all the cases, from Forgács to Andell, Aviad or Suri, they succeed in placing the narratives of these families in broader frameworks, providing the spectator with a deeper understanding of past times.

\section{References}

Bryceson, Deborah F., and Ulla Vuorela, ed. 2002. The Transnational famil: New European frontiers and global networks. Oxford: Berg.

Cuevas, Efrén. 2013. "Home Movies as Personal Archives in Autobiographical Documentaries," Studies in Documentary Film, forthcoming 2013.

De Certeau, Michel. 1984. The Practice of Everyday Life. Berkeley and Los Angeles: University of California Press.

Gregory, Brad S. 1999. "Is Small Beautiful? Microhistory and the History of Everyday Life." History and Theory 38: 100-10. 
Hagedoorn, B. (2009). “'Look what I found!': (Re-)crossing boundaries between public/private history and biography/autobiography in Péter Forgács' The Maelstrom." Studies in Documentary Film 3 (2): 177-92.

Highmore, Ben. 2002. “Questioning Everyday Life.” In Everyday Life Reader, edited by Ben Highmore, 1-34. London: Routledge.

Ishizuka, Karen L. 2010. "A través de nuestros propios ojos. El cine realizado con metraje doméstico japonés-americano." La casa abierta. El cine doméstico y sus reciclajes contemporáneos, edited by Cuevas, Efrén, 207-23. Madrid: Ocho y medio.

Langford, Rachael. 2005. "Colonial false memory syndrome? The Cinémémoire archive of French colonial films and Mémoire d'Outremer." Studies in French Cinema 5 (2): 99-110.

Lebow, Alisa. 2012. "The Camera as Peripatetic Migration Machine." In The Cinema of Me: The Self and Subjectivity in First Person Documentary, edited by Alisa Lebow, 219-32. London and New York: Wallflower Press.

Levi, Giovanni. 2001. "On Microhistory." In New Perspectives on Historical Writing, edited by Peter Burke, $2^{\text {nd }}$ ed., 97-119. University Park: Pennsylvania State University Press.

Lüdtke, Alf. 1995. "What Is the History of Everyday Life and Who Are Its Practitioners?" In History of Everyday Life: Reconstructing Historical Experiences and Ways of Life, edited by Alf Lüdtke, 3-40. Ewin: Princeton University Press.

Muir, Edward. 1991. "Introduction: Observing Trifles". In Microhistory and the Lost Peoples of Europe, edited by Edward Muir and Guido Ruggiero, vii-xxviii. Baltimore and London: Johns Hopkins University Press.

Nichols, Bill and Michael Renov, ed. 2011. Cinema's Alchemist: The Films of Péter Forgács. Minneapolis: University of Minnesota Press.

Odin, Roger. 1995. "Le film de famille dans l'institution familiale." In Le film de famille. Usage privage, usage public, edited by Roger Odin, 27-39. Paris: Meridiens Klincksieck.

—. 2008. "Reflections on the Family Home Movie as Document: A Semio-pragmatic Approach." In Mining the Home Movies: Excavations in Histories and Memories, edited by Karen L. Ishizuka and Patricia R. Zimmermann, 255-271. Berkeley and Los Angeles: University of California Press.

Renov, Michael. 2002. "Historische Diskurse des Unvorstellbaren. Peter Forgacs' The Maelstrom." Montage/av 11 (1): 26-41.

Revel, Jacques. 1996. "Micro-analyse et constrution du social." In Jeux d'echelles. La micro-analyse à la expérience, edited by Jacques Revel, 19-30. Paris, Seuil/Gallimard. 
Roth, Michael S. 2008. "Ordinary Film. Peter Forgacs' The Maelstrom.” In Mining the Home Movies: Excavations in Histories and Memories, edited by Karen L. Ishizuka and Patricia R. Zimmermann, 62-72. Berkeley and Los Angeles: University of California Press.

Rosen, Robert. 2008. "Something Strong Within as Historical Memory." In Mining the Home Movies: Excavations in Histories and Memories, edited by Karen L. Ishizuka and Patricia R. Zimmermann, 107-21. Berkeley and Los Angeles: University of California Press.

Trivellato, Francesca. 2011. "Is There a Future for Italian Microhistory in the Age of Global History?" California Italian Studies 2 (1). http://escholarship.org/uc/item/0z94n9hq

Zimmermann, Patricia R. 2008. 'The Home Movie Movement: Excavations, Artifacts." In Mining the Home Movies: Excavations in Histories and Memories, edited by Karen L. Ishizuka and Patricia R. Zimmermann, 1-28. Berkeley and Los Angeles: University of California Press.

\section{Notes}

${ }^{1}$ I addressed these issues in Cuevas (2007). This chapter develops some of the main ideas outlined in that article, improved and complemented with new references and films.

${ }^{2}$ It exceeds the scope of this chapter to examine the differences between microhistory and Alltagsgeschichte, or among practitioners of microhistory. For an introductory comparative analysis, see Gregory (1999) and Trivellato (2011).

${ }^{3}$ Since most of the titles are little known, I provide information here about availability for purchase. Liner Nahimov is not available for sale; Mémoire d'outremer is available at www.circuit-court.org; Something Strong Within, at www.janm.org.

${ }^{4}$ Nevertheless, the differences between amateur and home moviemaking are not always clear-cut, depending on the situations portrayed, the purpose of the shooting. In the case of Memory of Overseas Territories there are sequences that come closer to a standard amateur film, like the harvesting scenes in "la région de Souk El Khemis," or the one showing the "Mission Ophtalmologique Saharianne." But most of the sequences fit more properly with home moviemaking, in following the activities of their filmmakers' families, like weddings, First Holy Communions, hunting excursions, etc.

${ }^{5}$ The quotation comes from the original English version of the chapter-available on www.efrencuevas.com-published in Spanish in Cuevas (2010).

${ }^{6}$ The efforts of Nakamura and Ishizuka go beyond the making of this film, and are visible in their work at the Japanese American National Museum. One of their most 
remarkable successes was the inclusion of the film Topaz (edited by home moviemaker Dave Tatsuno with material he shot at this camp) in the U.S. National Film Registry, the second non-professional film included after the Zapruder film. See Ishizuka and Zimmermann (2011, 126-141).

${ }^{7}$ Forgács's films have not been released on commercial DVD, with the exception of Hunky Blues: The American Dream. $Y$ in Vyvorg can be ordered from the production company Of Course My Films; For My Children is for sale on www.third-ear.com; I for India is available commercially.

${ }^{8}$ Although it is not my ambition here to make an exhaustive study of documentaries made with this approach, it is worthwhile to mention another documentary series, somehow close to the scope and goals of Forgács's films: Private Century. Made by Jan Šikl for Czech television, using home movies from the 1920s to the 1960s, it is composed of eight 52-minute episodes, each dealing with the life of a different family.

${ }^{9}$ Besides the numerous references to the film in other analyses of Forgács's films, The Maelstrom has been studied specifically by Renov (2002), Roth (2008), and Hagedoorn (2009). The articles of Renov and Roth are also available in Nichols and Renov (2011). In addition, two new essays on Forgács's work, by Ruth Balint and Richard Kilborn, are printed in this collection.

10 For a broader study of the different uses and values of home movies in autobiographical works, see Cuevas (2013). 